\title{
Effects of temperature on growth and stress hardening development of phytotron-grown seedlings of Aleppo pine (Pinus halepensis Mill.)
}

\author{
Manuel Fernández**, Antonio Royo, Luis Gil and José A. Pardos* \\ Dpto. de Silvopascicultura, Escuela Técnica Superior de Ingenieros de Montes, Universidad Politécnica de Madrid, 28040 Madrid, Spain
}

(Received 25 February 2002; accepted 24 June 2002)

\begin{abstract}
One year-old Pinus halepensis seedlings, grown in peat-vermiculite-pine bark mix in $200 \mathrm{~cm}^{3}$ containers, were moved to a growth chamber and submitted to a progressive decrease of temperature and photoperiod for three months. Morphological parameters and nutrient and non-structural carbohydrate content were measured. Root growth potential, freezing and drought resistance tests were assessed. Although height growth stopped when the minimum temperature fell below $9{ }^{\circ} \mathrm{C}$, shoot dry weight increased further. Needle potassium concentration and $\mathrm{K} / \mathrm{N}$ ratio increased progressively and significantly throughout the trial. This may be attributed to potassium accumulation. As height growth stopped, physiological changes were detected in shoot nitrogen and soluble sugar concentrations, root activity and hydraulic conductance maintenance. Nevertheless, cold and drought resistance tests, as well as root regeneration potential, did not reveal any sign of plant stress tolerance until the minimum temperature decreased to $8{ }^{\circ} \mathrm{C}$ and photoperiod to $9 \mathrm{~h}$. This latter temperature may be considered to be the threshold for Pinus halepensis to accumulate the required chilling hours that make seedlings suitable for afforestation purposes. At least, more than 330 chilling hours $\left(\leq 8^{\circ} \mathrm{C}\right)$ are required to reach a minimum level of stress hardiness. The Fv/Fm chlorophyll fluorescence ratio, measured just one day after the freezing test, provides a good estimate of plant frost tolerance.
\end{abstract}

Pinus halepensis / plant quality / stress tolerance / chilling hours / chlorophyll fluorescence / plant nutrition

Résumé - Effets de la température sur la croissance et le développement de la résistance au stress de semis de Pin d'Alep (Pinus halepensis Mill.). Des semis de Pin d'Alep (Pinus halepensis), âgés d'un an, croissant sur un mélange de tourbe-vermiculite-écorce de pin dans des containers de $200 \mathrm{~cm}^{3}$, ont été mis en place dans une chambre de croissance et soumis, pour une période de 3 mois, à une température et photopériode décroissant progressivement. Des paramètres morphologiques, de nutrition et de teneur carbonée non structurale ont été mesurés. Des tests de potentiel de croissance racinaire, de résistance au froid et à la sécheresse ont été réalisés. Bien que la croissance en hauteur se soit arrêtée lorsque la température minimum eu atteint $9^{\circ} \mathrm{C}$, la masse sèche des pousses continue d'augmenter. La concentration en potassium des aiguilles, le rapport $\mathrm{K} / \mathrm{N}$ augmente progressivement et significativement au cours de l'essai. Ceci peut être attribué à une accumulation de potassium. Lorsque la croissance en hauteur s'est arrêtée, des changements physiologiques ont été constatés pour la concentration en azote et en sucre soluble des pousses, dans l'activité des racines et dans le maintien de la conductance hydraulique. Cependant, les tests de résistance au froid et à la sécheresse, de même que le potentiel de régénération racinaire, ne révélèrent aucun signe de tolérance de la plante au stress jusqu'à ce que la température minimum décroisse à $8{ }^{\circ} \mathrm{C}$ et la photopériode à $9 \mathrm{~h}$. Cette dernière température pourrait être considérée, pour Pinus halepensis, comme le seuil d'accumulation des heures de froid qui sont nécessaires avant une utilisation en milieu forestier. Plus de 330 heures de froid $\left(<8{ }^{\circ} \mathrm{C}\right)$ sont nécessaires pour atteindre le niveau minimum de résistance au stress. Le rapport Fv/Fm de fluorescence de la chlorophylle, mesuré juste le jour suivant après le test au froid, donne une bonne estimation de la tolérance du plant au froid.

Pinus halepensis / qualité des plants / tolérance au stress / heure de froid / fluorescence de la chlorophylle / nutrition des plants

\section{INTRODUCTION}

Genetic factors as well as nursery practices and environmental conditions affect seedling survival and growth in forest plantations [11, 24]. The evaluation of plant physiological quality provides useful information in order to reduce possible plantation failures. Linking readily measured morphological and physiological attributes $[9,14,18,54]$ to survival and growth will be essential for a proper evaluation.

Fall planting is an alternative to spring planting if drought periods are frequent in spring [53]. In regions with a Mediterranean climate, fall planting could be beneficial due to the root growth during this time and the subsequent avoidance of a possible spring drought period. However, fall planted

* Correspondence and reprints

Tel.: (34) 91 3367113; fax: (34) 91 5439557; e-mail: jpardos@ montes.upm.es

** Current address: Dpto. Ciencias Agroforestales, Escuela Politécnica Superior, Universidad de Huelva, 21819, La Rábida, Palos de La Frontera, Huelva, Spain. 
Table I. Culture conditions inside the growth chamber. $\mathrm{T}=$ temperature. $\mathrm{RH}=$ relative humidity. First harvest on 26/05; second harvest on 12/06; third harvest on 6/07; and fourth harvest on $27 / 07$.

\begin{tabular}{cccccc}
\hline \multicolumn{1}{c}{ Date } & \multicolumn{2}{c}{$\mathrm{T}\left({ }^{\circ} \mathrm{C}\right)$} & \multicolumn{2}{c}{ RH $(\%)$} & Photoperiod \\
\hline & Day & Night & Day & Night & (h) \\
\hline $05 / 05$ to $25 / 05$ & 22.0 & 15 & 70 & 80 & 16 \\
$26 / 05$ to $01 / 06$ & 21.5 & 14 & 70 & 80 & 15 \\
$02 / 06$ to $08 / 06$ & 21.0 & 13 & 70 & 80 & 14 \\
$09 / 06$ to $15 / 06$ & 20.5 & 12 & 70 & 80 & 13 \\
$16 / 06$ to $22 / 06$ & 20.0 & 11 & 70 & 80 & 12 \\
$23 / 06$ to $29 / 06$ & 19.5 & 10 & 70 & 90 & 11 \\
$30 / 06$ to $06 / 07$ & 19.0 & 9 & 70 & 90 & 10 \\
$07 / 07$ to $13 / 07$ & 18.5 & 8 & 70 & 90 & 9 \\
$14 / 07$ to $20 / 07$ & 17.5 & 7 & 70 & 90 & 8 \\
$21 / 07$ to $27 / 07$ & 17.0 & 6 & 70 & 90 & 8 \\
\hline
\end{tabular}

seedlings are threatened by early frosts, so it is necessary to know when the seedlings are tolerant to low temperature conditions before they are planted.

Seedlings that are actively growing in the nursery must be prepared for the shock of lifting, packing and outplanting. This conditioning treatment involves inducing a dormant condition in the seedling. Most North American nurseries reduce irrigation or fertilisation in late summer and fall as a part of this conditioning process $[34,66]$. Nevertheless, these latter treatments have not always been effective in inducing plant dormancy in Pinus halepensis seedlings [56, 63]. This species shows osmotic adjustment as a response to water stress, although the response varies between the provenances [10]. On the contrary, temperature and photoperiod are important factors controlling growth, dormancy and low temperature tolerance $[17,46]$. They also cause metabolic responses (e.g. osmotic adjustment) similar to those caused by moderate water stress [20,39]. Nothing, however, induces dormancy as well as cold weather. The growth-dormancy cycle in temperate trees is an adaptation to avoid plant injury in cold weather [34]. To measure the probable depth of dormancy, many nursery managers record the number of chilling hours. The geographic seed source of a seedling determines the number of chilling hours required for dormancy (usually between 200 and 400).

The present paper describes the effect of a gradual decrease in temperature and photoperiod on growth and hardening in Pinus halepensis seedlings. The major objective of this treatment is to determine when stress hardening occurs and consequently when seedlings would be ready for outplanting. This species never sets a bud at the end of the first growing season and probably remains in a quiescent state, making it difficult to observe morphological changes with hardening. Therefore, several morphological and physiological attributes were taken into account in order to achieve the cited objective and to estimate plant quality.

\section{MATERIALS AND METHODS}

One year-old Pinus halepensis Mill. seedlings, Levante Interior provenance [21] were firstly grown at La Hunde nursery (Valencia,
Spain). Seedlings were cultivated in the open air in a Sphagnum peatvermiculite-pine bark mix $(3: 1: 1 \mathrm{v} / \mathrm{v}), 200 \mathrm{~cm}^{3}$ per plant (Forest Pot ${ }^{\circledR}$ 200 trays). Ten trays with 50 seedlings per tray were taken out. A preconditioning experiment was carried out over three months. The seedlings were placed inside a growth chamber and left for three weeks (May, 5-25) with long days, favourable temperature and water supply, similar growing conditions to those registered at the nursery when seedlings were lifted. Afterwards, temperature and photoperiod were varied as shown in table I. Temperature was programmed to simulate the mean values registered at the nursery from early September to the end of November. As happens in natural conditions, photoperiod was also progressively reduced.

The mean photosynthetic active radiation (PAR) was $350 \mu \mathrm{mol} \mathrm{m} \mathrm{m}^{-2} \mathrm{~s}^{-1}$ in the middle of the growth chamber, falling to $200 \mu \mathrm{mol} \mathrm{m} \mathrm{m}^{-2} \mathrm{~s}^{-1}$ in the edges; so the trays were rotated weekly. A Peters ${ }^{\circledR}$ fertiliser (20-7-19), at a $500 \mathrm{mg} \mathrm{L}^{-1}$ concentration, was applied twice a week, two litres per tray ( $40 \mathrm{~mL}$ per plant) each time.

About every three weeks (May 26, June 12, July 6, July 27) 84 seedlings were taken out from the growth chamber and the following parameters were evaluated:

Morphology and growth. In each harvest, 15 seedlings were harvested. The following parameters were measured: height above the cotyledons insertion $(\mathrm{H})$; diameter one centimetre below cotyledons insertion (D); number of branches; and shoot and root dry weights after 48 hours oven drying at $70{ }^{\circ} \mathrm{C}$ (SDW and RDW respectively). Also total dry weight (TDW) and shoot/root dry weight ratio (SDW/RDW) were calculated. In another 20 plants, not harvested, height and diameter were also measured in the same way as before every harvest date.

Mineral nutrients and carbohydrates content. 12 seedlings, clustered together in three groups of four plants, were also harvested for analysis of macronutrients (N, P, K), soluble sugars (SS) and starch (St) content in shoot and root portions. The following analytical procedures were applied: Kjeldhal for N (Kjeltec system 1026, Tecator; Höganas, Sweden), blue-molybdate colorimetry for P, flame photometry for K (Flame photometer 410, Corning Ltd, Essex, England), hydroalcoholic extraction and colorimetric titration with anthrone for soluble sugars [60], and acidic hydrolysis followed by titration with anthrone for starch [55]. A spectrophotometer (UV-1601, Shimadzu, Tokyo, Japan) was used for P, SS and St analysis.

Mineral nutrient (concentration Y-axis; total content X-axis), as well as dry mass values, were used to draw nomograms which show relative changes occurring in these parameters in the successive harvests. Variation is showed by the magnitude and direction of individual linear responses (vectors).

Root growth potential (RGP). This test quantifies the ability of a seedling to initiate and elongate new roots within a prescribed period of time in a standard environment designed to optimise root growth. The procedure described by Ritchie [50] was followed. The number and length of white roots were recorded in 15 plants at each harvest (4 times). White roots were counted and root apexes cut off. Afterwards seedlings were replanted in $500 \mathrm{~cm}^{3}$ containers with a peatvermiculite-perlite mixture $(2: 1: 1 \mathrm{v} / \mathrm{v})$ and put in a air-conditioned greenhouse. After four weeks the regenerated roots were processed as before. The greenhouse temperature was set at $27^{\circ} \mathrm{C}$ (day) and $17^{\circ} \mathrm{C}$ (night). The natural photoperiod was not modified.

Whole-plant freezing test (WPFT). At each harvest, 5 plants were taken as the control and another 15 were exposed to a slow decrease in temperature $\left(3{ }^{\circ} \mathrm{C} / \mathrm{h}\right)$ up to $-8{ }^{\circ} \mathrm{C}$. The roots were buffered from the low temperature by surrounding them with Styrofoam. Root temperature was incessantly measured with a thermometer, and it did not go down $-2{ }^{\circ} \mathrm{C}$ during the assay. The temperature recommended for cold-hardiness test for this species is -8 to $-10^{\circ} \mathrm{C}$ [56]. After three hours at $-8^{\circ} \mathrm{C}$, the temperature was increased $5^{\circ} \mathrm{C} \mathrm{h}^{-1}$ up to room temperature and the plants were taken to a growth chamber at 
Table II. Means $( \pm$ SE) of morphological attributes in the four harvests. Height $(H)$, stem diameter (D), shoot dry weight (SDW), root dry weight (RDW), and shoot to root dry weight ratio (SDW/RDW). Different letters in the same row indicate significant differences (Tukey HSD, $95 \%)$.

\begin{tabular}{lcccc}
\hline & 1st harvest & 2nd harvest & 3rd harvest & 4th harvest \\
\hline $\mathrm{H}(\mathrm{cm})$ & $12.8 \pm 0.5 \mathrm{a}$ & $16.8 \pm 0.7 \mathrm{~b}$ & $17.5 \pm 0.8 \mathrm{~b}$ & $17.8 \pm 0.6 \mathrm{~b}$ \\
$\mathrm{D}(\mathrm{mm})$ & $2.9 \pm 0.1 \mathrm{a}$ & $3.2 \pm 0.1 \mathrm{ab}$ & $3.3 \pm 0.1 \mathrm{ab}$ & $3.5 \pm 0.1 \mathrm{~b}$ \\
SDW (g) & $1.71 \pm 0.04 \mathrm{a}$ & $1.92 \pm 0.04 \mathrm{ab}$ & $2.21 \pm 0.06 \mathrm{ab}$ & $2.37 \pm 0.06 \mathrm{~b}$ \\
RDW (g) & $1.18 \pm 0.03 \mathrm{a}$ & $1.22 \pm 0.03 \mathrm{a}$ & $1.50 \pm 0.15 \mathrm{a}$ & $1.44 \pm 0.13 \mathrm{a}$ \\
SDW/RDW & $1.40 \pm 0.06 \mathrm{a}$ & $1.62 \pm 0.09 \mathrm{a}$ & $1.45 \pm 0.09 \mathrm{a}$ & $1.56 \pm 0.06 \mathrm{a}$ \\
\hline
\end{tabular}

$22 / 16^{\circ} \mathrm{C}, 70 / 80 \%$ relative humidity, $16 \mathrm{~h}$ photoperiod and $200 \mu \mathrm{mol} \mathrm{m}{ }^{-2} \mathrm{~s}^{-1}$ PAR. On the first, third and fourteenth days chlorophyll fluorescence, Fv/Fm ratio, was measured (Plant Stress Meter, Biomonitor, AB, Sweden) two hours after the beginning of the light period. Needles were placed for 30 minutes in darkness before measurements were taken. Two months later, the observed damage in the shoot were quantitatively estimated according to the proportion of withered needles, at the following six levels: $0=0 \%$ dead needles, $1=1-20 \%, 2=21-40 \%, 3=41-60 \%, 4=61-80 \%, 5=81-100 \%$ (or dead seedling).

Drought resistance test. In each harvest, 22 plants were lifted and their root systems washed to eliminate the growing medium. The whole plants were subjected to $32{ }^{\circ} \mathrm{C}$ temperature and $30 \%$ relative humidity for 15 minutes and then roots were placed in water for 5 minutes for rehydration. Another fourteen plants, used as control, were not submitted to the dry atmosphere. 10 control plants and 15 tested plants were put in $500 \mathrm{~cm}^{3}$ containers as in the RGP test, taken to the greenhouse and chlorophyll fluorescence and shoot damage were measured as in the WPFT. The remaining plants were used for hydraulic conductance measurements, following the procedure ("mille-pates") used by Bréda and Ménard [7], modified from that described by Sperry et al. [59]. This procedure is based on the measure of hydraulic conductance of xylem in a stem segment before and after the removal of all emboli. Briefly, 2.5-3.0 cm hypocotyl stem segments were cut under water, the bark removed and the proximal end of the stem section securely attached to a tubing containing a solution of filtered $(0.45 \mu \mathrm{m})$ degassed acidified distilled water $(\mathrm{HCl}$, $\mathrm{pH}=2.0$ ). The solution in the tubing was pressurized to $6.5 \mathrm{kPa}$ by gravity to measure initial hydraulic conductance, and to $1.5 \mathrm{MPa}$ for 15 minutes to remove emboli and measure maximum hydraulic conductance. Finally, the percentage loss of hydraulic conductance was calculated from the difference in maximum and initial hydraulic conductance.

Statistical analysis. One factor variance analysis was applied to data (BMDP Statistical Software Inc., Cork, Ireland), each harvest being taken as a fixed factor. Prior to analysis all parameters were examined for normal distribution and variance equality. No data transformations were necessary. The Tukey HSD test (Tukey Honest Significant Difference) was applied for means comparison when differences were significant $(P \leq 0.05)$.

Correlation analysis was used to examine relationship between the shoot damage coefficient and the Fv/Fm values in the WPFT and drought resistance tests. Control and tested plant differences were analysed by one factor variance analysis as well.

\section{RESULTS}

Of the four measured growth variables, all excepted root dry weight increased numerically from the first to last harvest.

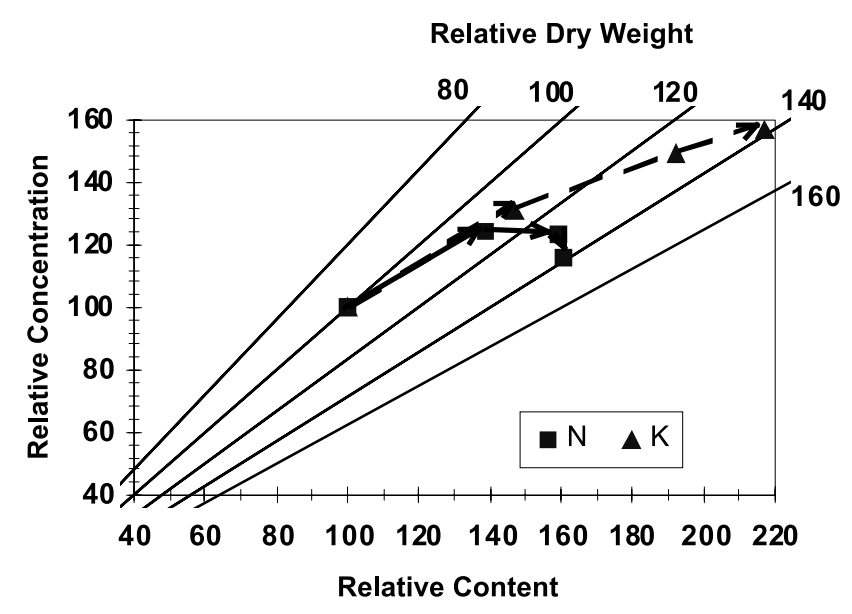

Figure 1. Nomogram of relative changes occurring at 3-week intervals in needle dry weight, and needle nitrogen $(\mathrm{N})$ and potassium (K) composition. Vectors reflect progression in time from harvest 1 to 4 .

However, patterns of statistical significance varied even more (table II). There was a significant height increment between the first and the second harvests. However, from the second to the fourth harvests the height increase was not significant. Like height, stem diameter and shoot dry weight showed a continuous increase throughout the assay, but mean differences were only significant between the first and the fourth harvests. With regard to root dry weight and shoot to root dry weight ratio, their mean values did not vary significantly during the experiment.

Foliar nitrogen and potassium concentrations varied significantly during the assay, but not for foliar $\mathrm{P}$ or root nutrient concentrations (table III). Both $\mathrm{N}$ and $\mathrm{K}$, increased in foliar concentration in spite of the increase of dry mass, however their patterns were something different (figure 1).

Shoot soluble sugar concentration showed a similar pattern to that of foliar potassium. Root non-structural carbohydrates concentration $(\mathrm{SS}+\mathrm{St})$ showed a relative minimum in the third harvest (table III). Between the 2 nd and the 3 rd harvests, a significant increase of shoot soluble sugar concentration paralleled a significant decrease in non-structural carbohydrate concentration in the roots. At the fourth harvest, nonstructural carbohydrate concentration increased to its previous high values, while SS concentration in the shoot was maintained. 
Table III. Mean values $( \pm \mathrm{SE})$ of macronutrient $(\mathrm{N}, \mathrm{P}, \mathrm{K})$ concentration in needles and roots for the four harvests, and mean values $( \pm \mathrm{SE})$ of non-structural carbohydrates (starch, St, and soluble sugars, SS) concentration in shoot and roots for the four harvests. Different letters in the same row indicate significant differences (Tukey HSD, 95\%).

\begin{tabular}{|c|c|c|c|c|}
\hline & 1st harvest & 2nd harvest & 3rd harvest & 4th harvest \\
\hline \multicolumn{5}{|l|}{ Needles } \\
\hline $\mathrm{N}(\%)$ & $1.46 \pm 0.05 \mathrm{a}$ & $1.81 \pm 0.05 \mathrm{~b}$ & $1.80 \pm 0.04 \mathrm{~b}$ & $1.70 \pm 0.06 \mathrm{~b}$ \\
\hline $\mathrm{P}(\%)$ & $0.17 \pm 0.02 \mathrm{a}$ & $0.23 \pm 0.02 \mathrm{a}$ & $0.20 \pm 0.01 \mathrm{a}$ & $0.20 \pm 0.00 \mathrm{a}$ \\
\hline $\mathrm{K}(\%)$ & $0.74 \pm 0.12 \mathrm{a}$ & $0.97 \pm 0.03 \mathrm{ab}$ & $1.10 \pm 0.09 \mathrm{~b}$ & $1.16 \pm 0.02 b$ \\
\hline \multicolumn{5}{|l|}{ Shoot } \\
\hline St $\left(\mathrm{mg} \mathrm{g}^{-1}\right)$ & $53.9 \pm 11.9 \mathrm{a}$ & $50.7 \pm 2.62 \mathrm{a}$ & $59.6 \pm 7.9 \mathrm{a}$ & $55.9 \pm 2.0 \mathrm{a}$ \\
\hline $\mathrm{SS}\left(\mathrm{mg} \mathrm{g}^{-1}\right)$ & $36.7 \pm 1.7 \mathrm{a}$ & $38.2 \pm 0.3 \mathrm{a}$ & $51.3 \pm 1.7 \mathrm{~b}$ & $51.8 \pm 0.4 \mathrm{~b}$ \\
\hline \multicolumn{5}{|l|}{ Roots } \\
\hline $\mathrm{N}(\%)$ & $1.16 \pm 0.10 \mathrm{a}$ & $1.23 \pm 0.07 \mathrm{a}$ & $1.30 \pm 0.03 \mathrm{a}$ & $1.23 \pm 0.05 \mathrm{a}$ \\
\hline $\mathrm{P}(\%)$ & $0.23 \pm 0.02 \mathrm{a}$ & $0.23 \pm 0.02 \mathrm{a}$ & $0.25 \pm 0.01 \mathrm{a}$ & $0.30 \pm 0.01 \mathrm{a}$ \\
\hline $\mathrm{K}(\%)$ & $0.61 \pm 0.04 \mathrm{a}$ & $0.59 \pm 0.03 \mathrm{a}$ & $0.60 \pm 0.01 \mathrm{a}$ & $0.70 \pm 0.02 \mathrm{a}$ \\
\hline St $\left(\mathrm{mg} \mathrm{g}^{-1}\right)$ & $82.9 \pm 8.6 \mathrm{~b}$ & $66.3 \pm 5.3 \mathrm{ab}$ & $51.1 \pm 5.2 \mathrm{a}$ & $66.7 \pm 5.3 \mathrm{ab}$ \\
\hline $\mathrm{SS}\left(\mathrm{mg} \mathrm{g}^{-1}\right)$ & $17.2 \pm 1.1 \mathrm{~b}$ & $22.1 \pm 3.6 \mathrm{~b}$ & $8.9 \pm 0.7 \mathrm{a}$ & $24.4 \pm 3.1 \mathrm{~b}$ \\
\hline
\end{tabular}

Table IV. Roots mean length $( \pm \mathrm{SE})$ following the RGP test in the for harvests. Different letters in the same row indicate significant differences (Tukey HSD, 95\%).

\begin{tabular}{lcccc}
\hline & 1st harvest & 2nd harvest & 3rd harvest & 4th harvest \\
\hline Initial roots $(\mathrm{mm})$ & $305.9 \pm 32.3 \mathrm{~b}$ & $196.7 \pm 34.7 \mathrm{ab}$ & $86.7 \pm 1.47 \mathrm{a}$ & $120.0 \pm 26.3 \mathrm{a}$ \\
Regenerated roots $(\mathrm{mm})$ & $1.0 \pm 0.7 \mathrm{a}$ & $0.3 \pm 0.3 \mathrm{a}$ & $0.1 \pm 0.2 \mathrm{a}$ & $73.0 \pm 56.0 \mathrm{~b}$ \\
\hline
\end{tabular}

Table V. Shoot damage coefficients following the drought resistance test two months after every harvest, and chlorophyll fluorescence mean values (Fv/Fm). Different letters in the same row indicate significant differences (Tukey HSD, 95\%).

\begin{tabular}{|c|c|c|c|c|}
\hline & 1st harvest & 2nd harvest & 3rd harvest & 4th harvest \\
\hline \multicolumn{5}{|l|}{ Control plants } \\
\hline $\mathrm{Fv} / \mathrm{Fm}, 1$ st day & $0.780 \mathrm{~b}$ & $0.789 \mathrm{~b}$ & $0.726 \mathrm{a}$ & $0.770 \mathrm{~b}$ \\
\hline Fv/Fm, 3rd day & $0.785 \mathrm{c}$ & $0.798 \mathrm{c}$ & $0.714 \mathrm{a}$ & $0.753 \mathrm{~b}$ \\
\hline Fv/Fm, 14th day & $0.792 \mathrm{c}$ & $0.662 \mathrm{~b}$ & $0.426 \mathrm{a}$ & $0.758 \mathrm{bc}$ \\
\hline Damage coefficient & 3.85 & 4.15 & 4.25 & 3.35 \\
\hline \multicolumn{5}{|l|}{ Tested plants } \\
\hline Fv/Fm, 1st day & $0.787 \mathrm{~b}$ & $0.778 \mathrm{~b}$ & $0.732 \mathrm{a}$ & $0.742 \mathrm{a}$ \\
\hline $\mathrm{Fv} / \mathrm{Fm}, 3 \mathrm{rd}$ day & $0.786 \mathrm{c}$ & $0.759 \mathrm{~b}$ & $0.723 \mathrm{a}$ & $0.736 \mathrm{ab}$ \\
\hline $\mathrm{Fv} / \mathrm{Fm}, 14$ th day & $0.586 \mathrm{bc}$ & $0.436 \mathrm{ab}$ & $0.362 \mathrm{a}$ & $0.720 \mathrm{c}$ \\
\hline Damage coefficient & 5.00 & 5.00 & 5.00 & 4.25 \\
\hline
\end{tabular}

In roots, mean values of the $\mathrm{K} / \mathrm{N}$ ratio were always less than 0.57 (between 0.46 and 0.57 according to the harvest), while in needles this ratio was 0.51 and 0.54 in the first and second harvests, increasing significantly to 0.61 and 0.68 in the third and fourth harvests respectively. The ratio $\mathrm{P} / \mathrm{N}$ was between 0.11 and 0.13 in needles and between 0.19 and 0.24 in roots, without significant differences between harvests.

The root growth potential test revealed a significant decline in initial white roots length from the first to the third harvests, and a significant increase of regenerated root length between the third and the fourth harvests (table IV). Regenerated root length did not vary significantly between the first and the third harvests. In the drought resistance test (table $V$ ), a highly significant relationship was found between shoot damage after two months and the variable to maximum fluorescence ratio $\left(\mathrm{Fv} / \mathrm{Fm}\right.$ ) after two weeks, $\mathrm{r}^{2}=0.79$ (figure 2

The percentage loss in hydraulic conductance diminished between the second and third measurements in both the control and tested plants (table VI), indicating a reduction in the presence of emboli in the vascular system. In the first two harvests the percentage loss in hydraulic conductance was between 16 and $19 \%$ greater in tested than in control plants. In the last two harvests the percentage loss in hydraulic conductance was reduced to less than $6 \%$ in tested plants, 
Table VI. Mean value $( \pm \mathrm{SE})$ of the lost in hydraulic conductance $(\%)$ in the four harvests. Different letters in the same row indicate significant differences (Tukey HSD, 95\%).

\begin{tabular}{lcccc}
\hline & 1st harvest & 2nd harvest & 3rd harvest & 4th harvest \\
\hline Control plants & $12.9 \pm 2.9 \mathrm{a}$ & $10.0 \pm 16.1 \mathrm{~b}$ & $2.0 \pm 8.0 \mathrm{ab}$ & $0.0 \pm 2.4 \mathrm{~b}$ \\
Tested plants & $29.0 \pm 7.0 \mathrm{a}$ & $28.6 \pm 23.6 \mathrm{a}$ & $3.8 \pm 35.7 \mathrm{ab}$ & $5.7 \pm 9.0 \mathrm{~b}$ \\
\hline
\end{tabular}

Table VII. Chlorophyll fluorescence values (Fv/Fm) the following day and three days after the freezing test, and shoot damage coefficient after two months in the four harvests. Different letters in the same row indicate significant differences (Tukey HSD, 95\%).

\begin{tabular}{|c|c|c|c|c|}
\hline & 1st harvest & 2nd harvest & 3rd harvest & 4th harvest \\
\hline \multicolumn{5}{|l|}{ Control plants } \\
\hline 1 st day & $0.798 \mathrm{~b}$ & $0.789 \mathrm{~b}$ & $0.726 \mathrm{a}$ & $0.771 \mathrm{~b}$ \\
\hline 3rd day & --- & $0.798 \mathrm{~b}$ & $0.714 \mathrm{a}$ & $0.753 \mathrm{ab}$ \\
\hline Damage coefficient & 0.10 & 0.05 & 0.20 & 0.15 \\
\hline \multicolumn{5}{|l|}{ Tested plants } \\
\hline 1 st day & $0.021 \mathrm{a}$ & $0.080 \mathrm{a}$ & $0.058 \mathrm{a}$ & $0.544 \mathrm{~b}$ \\
\hline 3rd day & --- & $0.023 \mathrm{a}$ & $0.019 \mathrm{a}$ & $0.514 \mathrm{~b}$ \\
\hline Damage coefficient & 5.00 & 5.00 & 5.00 & 4.20 \\
\hline
\end{tabular}

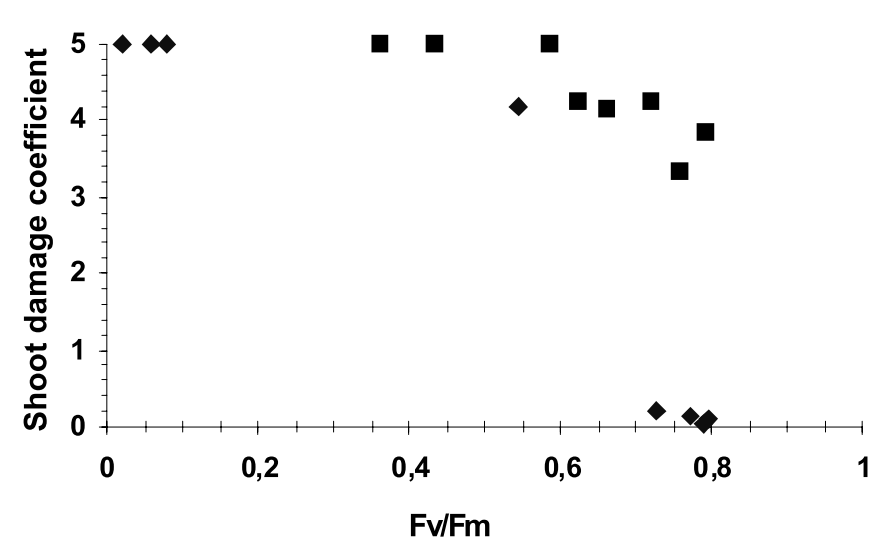

Figure 2. The relationship between chlorophyll fluorescence values (Fv/Fm) after 2 weeks and the shoot damage coefficient (after 2 months) for the drought resistance test $\left(\mathbf{m}, \mathrm{y}=-7.8577 \mathrm{x}^{2}+5.643 \mathrm{x}+\right.$ $4.027, \mathrm{r}^{2}=0.79$ ). And the relationship between $\mathrm{Fv} / \mathrm{Fm}$ values (after 1 day) and shoot damage coefficient (after 2 months) for the freezing test $\left(\diamond, \mathrm{y}=-18.307 \mathrm{x}^{2}+8.386 \mathrm{x}+4.642, \mathrm{r}^{2}=0.97\right)$. Control and tested seedlings are included. Each point is the mean of 5 to 15 seedlings.

without significant differences with regard to the controls $(P=$ 0.213). A wide variation range was found within the second and third harvests.

The whole-plant freezing test was highly useful to discriminate between control and frozen plants for Fv/Fm and shoot damage values $(P \leq 0.030)$. In this test the shoot damage of the tested plants reached $100 \%$ in the first three harvests and $80 \%$ in the last one, while there were fewer than $20 \%$ dead needles in the controls whatever the harvest. The Fv/Fm values diminished in the frozen plants one day after the test was applied; this drop was larger for the first three harvests (table VII) and the drop coincided with their greater shoot damage. The significant relationship between shoot damage coefficient and Fv/Fm values in the WPFT is illustrated in figure $2(\bullet), \mathrm{r}^{2}=0.97$. Shoot damage appeared to increase very steeply as Fv/Fm values decreased below 0.74 .

\section{DISCUSSION}

There was a continuous increase in height as large as minimum temperature was greater than $10-11^{\circ} \mathrm{C}$ and photoperiod longer than 11-12 h, but height growth practically stopped at values lees than these. However, shoot dry weight increased during the whole assay, which indicates some cambial activity as increases in starch reserves in spite of the cessation of the apical meristem. This phenomenon is well known and broadly observed in conifer nursery plants $[19,41]$. Similar to our experiment, different growth patterns of shoot and root portions were obtained in Thuja plicata by a reduction in photoperiod [39].

The high nitrogen concentration reached in the needles between the first and the second harvests reveals a good nitrogen supply [57]. This increase in $\mathrm{N}$ concentration paralleled height growth. Afterwards, when height growth had stopped, nitrogen concentration was constant but the content increased in parallel to shoot dry weight. A near optimum foliar $\mathrm{N}$ concentration $[15,47,65]$ indicated a good nitrogen status of the plants. Therefore, since foliar nitrogen content and photosynthetic rate are closely related [32], nitrogen is not likely to be the cause of root growth limitation [44, 62] and growth resumption hindrance after transplanting whether environmental conditions were again favourable or not.

Needle potassium content and concentration increased during the whole experiment in higher proportion than nitrogen. This means a continuous potassium uptake and accumulation. This latter behaviour could mean a somewhat low initial potassium status or a insufficient potassium supply, acting then as a growth restricted factor [25]. However, we could suggest other explanation if we take into account the two following reasons. First, the ratio $\mathrm{K} / \mathrm{N}$ in the fertiliser was 0.79 , while it did not surpass 0.57 in the roots after 83 days (whole experiment) and in the needles after 45 days. Second, if it is possible to say that optimal concentration ranges for conifer needles are 1.4-2.2 for $\mathrm{N}, 0.2-0.4$ for $\mathrm{P}, 0.4-1.5 \%$ for $\mathrm{K}, 0.45-0.55$ for $\mathrm{K} / \mathrm{N}$ ratio and $0.14-0.20$ for the $\mathrm{P} / \mathrm{N}$ ratio $[28,29]$, then the nitrogen and potassium contents in the present assay, being close to these optimal ranges reveal a 
sufficient supply. Therefore, the alternative explanation is that the progressive accumulation of foliar potassium might mean potassium storage in order to increase plant drought [42] and frost [33] tolerance. In addition, the large increase in $\mathrm{K} / \mathrm{N}$ ratio after the second harvest would mean that the optimum $\mathrm{K} / \mathrm{N}$ value depends on the phenological state of the plant (increasing the needles values from $0.52-0.57$ in active growth up to $\geq 0.68$ in the winter rest). The $\mathrm{P} / \mathrm{N}$ ratio was significantly higher in roots than in needles, which indicates a greater partitioning to roots.

The N, P and $\mathrm{K}$ partitioning and variation during the assay, and the $\mathrm{K} / \mathrm{N}$ and $\mathrm{P} / \mathrm{N}$ ratios in needles and roots point out the advantage of using a fertiliser with lesser $\mathrm{N}$ and greater $\mathrm{P}$ and $\mathrm{K}$ proportions than the one supplied in this experiment. Such a fertiliser would favour root growth and the development of stress hardening. This recommendation has been already given for other species [16, 33, 61]. Moreover, it has been shown that a fertiliser with high levels of P and K (e.g., Peters ${ }^{\circledR} 4-25$ 35 fertiliser) increases the hardening state and plant quality in Pinus pinea [19] and Pinus halepensis [47]. An excessive nitrogen supply could extend the vegetative growth period and decrease cold-hardiness [26]. At the same time, high levels of potassium favour the tolerance to low temperature [5]. However, the ratio between nutrients seems to be more important than the content of each nutrient separately [30, 48].

The sharp increase of shoot soluble sugars content and concentration from the second to third harvest indicates a period of accumulation, coupled with the arrest of height growth, as an adaptive response to cold season onset $[1,45]$. This rise of soluble sugars in the shoot paralleled a decrease in non-structural carbohydrates in the roots, indicating the possibility of retranslocation and not a change in net storage. The decrease in root soluble sugars took place at the same time as the drop in the initial root activity (RGP test) and loss of hydraulic conductance. These latter effects indicate some physiological changes in the plants, just when minimum temperatures reached $9{ }^{\circ} \mathrm{C}$. No changes in root regeneration and cold and drought tolerance were noted at this period. There was no sign of plant hardiness until the last harvest, but the hardening process had not been completed as shoot damage coefficients were too high.

Chlorophyll fluorescence, expressed as the Fv/Fm ratio, is a good indicator of photosystem II efficiency and it has been used to estimate long term responses to cold and water stress assays [6]. Although chlorophyll fluorescence has been used as an indicator of hardening process and the development of dormancy $[2,4,23]$, sometimes dormancy and stress hardiness are acquired and lost differently, suggesting that they are independent physiological processes [27]. For example, in Picea mariana the $\mathrm{Fv} / \mathrm{Fm}$ fluorescence ratio was more useful in evaluating damage due to several kinds of stresses than in estimating the level of dormancy [13]. In the present study Fv/Fm values provided conclusive results the day after the coldhardiness assay but 14 days were required for changes in the drought resistance test. Similarly, in Malus domestica Fv/Fm was only affected by water stress after a long-term time span, while other parameters as photosynthetic rate were affected at both short- and long-term [40]. Therefore, Fv/Fm measurements predict shoot damage by low temperature earlier than the damage caused by water stress.
In the present study a sudden increment of shoot damage was found for Fv/Fm values lower than 0.74 (figure 2). Fv/Fm values below than 0.7 are linked to severe winter cold damage in Quercus suber (Aranda, personal communication), and to severe water stress in Pinus pinaster (unpublished data), both being Mediterranean species. For the cold resistance assay of the present study there was lack of intermediate points in the relationship between shoot damage and Fv/Fm values. This latter has been previously shown [57] as being related to its discrimination capacity of seedling cold hardiness estimation.

The accumulation of chilling hours during the acclimation period induces dormancy and increases the cold hardiness in many temperate species $[8,22,43,58]$. In Pinus halepensis, a high level of hardening is achieved if chilling requirements are completed [56]. The $0-5^{\circ} \mathrm{C}$ range to add chilling hours is reported as effective for many temperate forest species [35, 52]. Other temperature ranges have been proposed as chilling requirements: $\leq 7^{\circ} \mathrm{C}$ in fruit trees [22]; and $\leq 8^{\circ} \mathrm{C}$ in Pinus taeda [64]. For species adapted to warm climate the range $0-10{ }^{\circ} \mathrm{C}$ would be preferred [49], since they may have short chilling requirements or no chilling requirements at all [51]. Combining temperature and photoperiod, the $5{ }^{\circ} \mathrm{C}$ temperature (a 3-9 ${ }^{\circ} \mathrm{C}$ range according to species) together with a $9 \mathrm{~h}$ photoperiod, were established as the threshold of environment signals for the onset of dormancy development to resist low winter temperatures [36, 37]. In Pinus halepensis, Royo [56] found: (a) a good correlation between the number of days in the nursery with minimum temperature less than $10^{\circ} \mathrm{C}$ and field surviving; (b) 200 hours $\left(\leq 10^{\circ} \mathrm{C}\right)$ did not complete the chilling requirements and $840 \mathrm{~h}$ were required to reach the maximum cold hardiness.

At the final harvest, in the present study, seedlings had accumulated 518 hours $\leq 10^{\circ} \mathrm{C}$, or $329 \mathrm{~h} \leq 8^{\circ} \mathrm{C}$. On the contrary, increases of cold and drought tolerance and root regene-ration potential were found when minimum temperature decreased below $8^{\circ} \mathrm{C}$ (and photoperiod below $9 \mathrm{~h}$ ). This temperature value is at the top of the range marked by Lavender [35, 36] and is well matched with the nature of Pinus halepensis, a species adapted to warm climates. Additional hardening by short days might have been expected in deciduous species [31] and conifers of temperate regions [12, 27, 38]. However, sometimes this could not occur in conifers such as Pinus sylvestris (L.) and Picea abies (L.) Karst. [3], and there is no evidence in pines which do not set a bud their first year of life like maritime pine [43] or Pinus halepensis. Therefore, for this experiment, we might conclude that the effect of temperature is greater than that of photoperiod.

It can be concluded that a moderate chilling $\left(8-7^{\circ} \mathrm{C}\right.$, night temperature) marks the inflexion point for dormancy and hardening induction in Pinus halepensis. Nurserymen should not lift seedlings before these have been subjected for $330 \mathrm{~h}$ to this or a lower temperature, at least for the Levante Interior provenance. After this level of chilling has been reached, some plant quality attributes must be measured to estimate the grade of dormancy and the level of stress hardening. A whole-plant freezing test combined with chlorophyll fluorescence (Fv/Fm) ratio is recommended to estimate quickly frost tolerance in this species. Nevertheless, more research is needed to study photo- and thermoperiod effects and their interaction on seedling hardening process for Pinus halepensis. 
Acknowledgements: The authors are grateful to Dr. Irena Trnkova Farrel for checking of the English version. This research was supported by CICYT F096-005-C2-1 Forest Project.

\section{REFERENCES}

[1] Amundson R.G., Kohut R.J., Laurence J.A., Influence of foliar N on foliar soluble sugars and starch of red spruce sapling exposed to ambient and elevated ozone, Tree Physiol. 15 (1995) 167-174.

[2] Agati G., Mazzinghi P., Paola M.L., Fusi F., Cecchi G., The F685/ F730 chlorophyll fluorescence ratio as an indicator of chilling stress in plants, J. Plant Physiol. 148 (1996) 384-390.

[3] Aronsson A., Influence of photo- and thermoperiod on the initial stages of frost hardening and dehardening of phytotron-grown seedlings of Scots pine (Pinus sylvestris L.) and Norway spruce (Picea abies (L.) Karst.), Stud. For. Suec. 128 (1975) 1-20.

[4] Binder W.D., Fielder P., Mohammed G.H., L'Hirondelle S.J., Applications of chlorophyll fluorescence for stock quality assessment with different types of fluorometers, New Forests 13 (1997) 63-89.

[5] Bogeat-Triboulot M.B., Lévy G., Contribution of different solutes to the cell osmotic pressure in tap and lateral roots of maritime pine seedlings: effects of a potassium deficiency and of an allmacronutrient deficiency, Ann. Sci. For. 55 (1998) 315-327.

[6] Bolhàr-Nordenkampf H.R., Óquist G., Chlorophyll fluorescence as a tool in photosynthesis research, in: Doll D.O., Scurlock J.M.O., Bolhàr-Nordenkampf H.R., Leegood R.C., Long S.P. (Eds.), Photosynthesis and production in a changing environment, Chapman \& Hall, 1993, pp. 193-206.

[7] Bréda N., Ménard J.-E., Notice d'utilisation du mille-pattes. Laboratoire de Bioclimatologie et d'Écophysiologie Forestière, INRA Nancy, France, 1992.

[8] Burr K.E., The target seedling concepts: bud dormancy and coldhardiness, in: Rose R., Campbell S.J., Landis T.D. (Eds.), Target seedling symposium: Proc., Combined Meeting Western Forest Nursery Associations, USDA Forest Service, GTR RM-200, 1990, pp. 79-90.

[9] Burr K.E., Tinus R.W., Wallner S.J., King R.M., Relationships among cold hardiness, root growth potential and bud dormancy in three conifers, Tree Physiol. 5 (1989) 291-306.

[10] Calamassi R., Della Rocca G., Falusi M., Paoletti E., Strati S., Resistance to water stress in seedlings of eight European provenances of Pinus halepensis Mill., Ann. For. Sci. 58 (2001) 663-672.

[11] Cannell M.G.R., Tabbush P.M., Deans J.D., Hollinsworth M.K., Sheppard L.J., Philipson J.J., Murray M.B., Sitka spruce and Douglas-fir seedlings in the nursery and in cold storage: root growth potential, carbohydrate content, dormancy, frost hardiness and mitotic index, Forestry 63 (1990) 9-27.

[12] Coursolle C., Bigras F.S., Margolis F.A., Herbert C., Growth and hardening of four provenances of containerized white spruce (Picea glauca (Moench) Voss) seedlings in response to the duration of 16 h long-night treatments, New Forests 16 (1998) 155-166.

[13] Devisscher G., Huner N.P.A., Malek L., Variable chlorophyll $a$ fluorescence as a potential indicator of black spruce seedling freezing tolerance under nursery conditions, Tree Planters' Notes 46 (1995) 107-111.

[14] Duryea M.L., Evaluating seedling quality: importance to reforestation, in: Duryea M.L. (Ed.), Evaluating Seedling Quality: principles, procedures, and predictive abilities of major tests, Forest Research Laboratory, Oregon State University, Corvallis, OR, 1985, pp. 1-4.

[15] Duryea M.L., McClain K.M., Altering seedling physiology to improve reforestation success, in: Duryea M.L., Brown G.N (Eds.), Seedling physiology and reforestation success, Martinus Nijhoff/Dr W. Junk Publishers, Boston, 1984, pp. 77-114.

[16] Edwards I.K., The effects of mineral nutrition on hardening-off of container seedlings, in: Proc. Intermountain Forest Nursery Association, August 14-18, 1989, Bismarck, North Dakota, USDA Forest Service, Gen. Techn. Report RM-184, 1989.
[17] Ekramoddoullah A.K.M., Taylor D., Hawkins B.J., Characterization of a fall protein of sugar pine and detection of its homologue associated with frost hardiness of western white pine needles, Can. J. For. Res. 25 (1995) 1137-1147.

[18] Fernández M., Gil L., Pardos J.A., Supervivencia y crecimiento en vivero de plantas de cinco procedencias de Pinus pinaster Ait. bajo diferentes regímenes hídricos, Invest. Agr.: Sist. Recur. For. 5 (1996) 20-44.

[19] Fernández M., Puértolas J., Alonso J., Rodríguez M., Gil L., Pardos J.A., Efecto de la fertilización durante el periodo de endurecimiento sobre plantas de Pinus pinea L. producidas en contenedor, in: Junta de Castilla León (Ed.), Actas del 1er Simposio del pino piñonero (Pinus pinea L.), Tomo I. Valladolid (Spain), February 22-24, 2000, pp. 183-190.

[20] Folk R.S., Grossnickle S.C., Major J.E., Arnott J.T., Influence of nursery culture on western red cedar. II. Freezing tolerance and morphological development of fall- and spring-planted seedlings, New Forests 8 (1994) 231-247.

[21] Gil L., Díaz P., Jiménez M.P., Roldán M., Alía R., Agúndez D., de Miguel J., Martín S., de Tuero M., Las regiones de procedencia de Pinus halepensis Mill. en España, Organismo Autónomo Parques Nacionales, Madrid, 1996.

[22] Gil-Albert Velarde F., La ecología del árbol frutal, MAPA, Madrid, 1989.

[23] Gillies S.L., Binder W.D., The effect of sub-zero temperatures in the light and dark on cold-hardened, dehardened and newly flushed white spruce (Picea glauca [Moench.] Voss) seedlings, New Forests 13 (1997) 91-104.

[24] Grossnickle S.C., Folk R.S., Stock quality assessment: forecasting survival and performance on a reforestation site, Tree Planters' Notes 44 (1993) 113-121.

[25] Haase D.L., Rose R., Vector analysis and its use for interpreting plant nutrient shifts in response to silvicultural treatments, For. Sci. 41 (1995) 275-294.

[26] Hawkins B.J., Davradou M., Pier D., Shortt R., Frost hardiness and winter photosynthesis of Thuja plicata and Pseudotsuga menziesii seedlings grown at three rates of nitrogen and phosphorus supply, Can. J. For. Res. 25 (1995) 18-28.

[27] Hawkins C.D.B., Shewan K.B., Frost hardiness, height and dormancy of 15 short-day, nursery-treated interior spruce seed lots, Can. J. For. Res. 30 (2000) 1096-1105.

[28] Ingestad T., Macroelement nutrition of pine, spruce and birch seedlings in nutrient solutions, Medd. Skogsforsknings Inst. Stokolm, Sweden, 51 art. 7, 1962.

[29] Ingestad T., Mineral nutrient requirements of Pinus sylvestris and Picea abies seedlings, Physiol. Plant. 45 (1979) 373-380.

[30] Jalkanen A., Rikala R., Foliar nutrient composition in bareroot Pinus sylvestris nursery crops, New Forests 10 (1995) 225-237.

[31] Ketchie D.O., Cold resistance of apple trees through the year and its relationship to the physiological stages, Acta Hort. 168 (1985) 131137.

[32] Lambers H., Cambridge M.L., Konings H., Pons T.L., Causes and consequences of variation in growth rate and productivity of higher plants, SPB Academic Publishing bv, The Hague, The Netherlands, 1990.

[33] Landis T.D., Tinus R.W., McDonald S.E., Barnett J.P., Seedling nutrition and irrigation. The container tree nursery manual. Vol. 4, Agric. Handbook 674, USDA, Washington DC, 1989.

[34] Lantz C.W., Biesterfeldt R.C., Moorheal D.J., Aycock O.E., Barham R.O., Brissette J.C., Dierauf T.A., Dougherty P.M., Fryar R.D., Ross O.E., Schroeder R.A., Stauder A.F., Care and planting of Southern pine seedlings, U.S.D.A. Forest Service, Southern Region, Management Bulletin, RB-ME39, 1996.

[35] Lavender D.P., Environment and shoot growth of woody plants, Forest Research Laboratory, Oregon State University, Corvallis, OR, Res. pap. 45, 1981.

[36] Lavender D.P., Bud dormancy, in: Duryea M.L. (Ed.), Evaluating Seedling Quality: principles, procedures, and predictive abilities of major tests, Forest Research Laboratory, Oregon State University, Corvallis, OR, 1985, pp. 7-15. 
[37] Lavender D.P., Measuring phenology and dormancy, in: Lassoie J.P., Hinckley T.M. (Eds.), Techniques and approaches in forest tree ecophysiology, CRC Press, Inc., Boca Ratón, Florida, USA 1991, pp. 403-422.

[38] McDonald J.E., Lang G.A., Early development of bud dormancy in conifer seedlings, in: Plant dormancy: physiology, biochemistry and molecular biology, CAB International, Wallingford, UK, 1996, pp. 193-196.

[39] Major J.E., Grossnickle S.C., Folk R.S., Arnott J.T., Influence of nursery culture on western red cedar. I. Measurement of seedlings attributes before fall and spring planting, New Forests 8 (1994) 211-229.

[40] Massacci A., Jones H.G., Use of simultaneous analysis of gasexchange and chlorophyll fluorescence quenching for analysing the effects of water stress on photosynthesis in apple leaves, Trees 4 (1990) $1-8$.

[41] Miller B.D., Timer V.R., Nutrient dynamics and carbon partitioning in nutrient loaded Picea mariana (Mill.) B.S.P. seedlings during hardening, Scand. J. For. Res. 12 (1997) 122-129.

[42] Morgan J.M., Osmorregulation and water stress in higher plants, Ann. Rev. Plant. Physiol. 35 (1984) 299-319.

[43] Nguyen A., Dormling I., Kremer A., Characterization of Pinus pinaster seedling growth in different photo- and thermoperiods in a phytotron as a basis for early selection, Scand. J. For. Res. 10 (1995) 129-139.

[44] Noland T.L., Mohammed G.H., Scott M., The dependence of root growth potential on light level, photosynthesis rate, and root starch content in jack pine seedlings, New Forests 13 (1997) 105-119.

[45] Ögren E., Nilsson T., Sundblad L.G., Relationship between respiratory depletion of sugars and loss of cold hardiness in coniferous seedlings over-wintering at raised temperatures: indications of different sensitivities of spruce and pine, Plant Cell Environ. 20 (1997) 247-253.

[46] Oleksyn J., Tjoelker M.G., Reich P.B., Growth and biomass partitioning of populations of European Pinus sylvestris L. under simulated $50^{\circ}$ and $60^{\circ} \mathrm{N}$ daylength: evidence for photoperiodic ecotypes, New Phytol. 120 (1992) 561-574.

[47] Puértolas J., Fernández M., Pardos J.A., Effects of improved nursery fertilization in the use of Aleppo pine (Pinus halepensis Mill.) for afforestation of abandoned agricultural land, Proceedings of International Conference of Forest Ecosystem Restoration, Ecological and Economical Impacts of Restoration Processes in Secondary Coniferous Forests, April 2000, Viena, 2000.

[48] Rikala R., Repo T., The effect of late summer fertilization on the frost hardening of second-year Scots pine seedlings, New Forests 14 (1997) 33-44.

[49] Ritchie G.A., Assessing seedling quality, in: Duryea M.L., Landis T.D. (Eds.), Forest nursery manual: production of bareroot seedlings, Martinus Nijhoff/Dr. W. Junk Publishers, The Hague, 1984, pp. 243-259.

[50] Ritchie G.A., Root growth potential: principles, procedures and predictive ability, in: Duryea M.L. (Ed.), Proc. of Workshop evaluating seedling quality: principles, procedures, and predictive abilities of major tests, Oregon State University, Corvallis, OR, USA, 1985, pp. 93-105.

[51] Ritchie G.A., Dunlap J.R., Root growth potential: its development and expression in forest tree seedlings, N.Z.J. For. Sci. 10 (1980) 218-248.
[52] Roberts K.K., Zwiazek J.J., Periodic chilling exposure during nursery culture. Effects on growth, morphology and drought resistance of containerized white spruce seedlings, New Forests 18 (1999) 301-314.

[53] Rose R., Root growth potential and starch differences in seedlings of six families of genetically improved loblolly pine, For. Sci. 38 (1992) 448-456.

[54] Rose R., Carlson W.C., Morgan P., The target seedling concept, in: Rose R., Campbell S.J., Landis T.D. (Eds.), Target seedling symposium: Proc., Combined Meeting Western Forest Nursery Associations, USDA Forest Service, GTR RM-200, 1990, pp. 1-8.

[55] Rose R.W., Rose C.L., Omi S.K., Forry K.R., Durall D.M., Bigg, W.L., Starch determination by perchloric acid vs. enzymes: evaluating the accuracy and precision of six colorimetric methods, J. Agric. Food. Chem. 39 (1991) 2-11.

[56] Royo A., La calidad de la planta forestal y su relación con el comportamiento en campo. Aplicación a Pinus halepensis Mill., Pinus pinaster Ait. y Quercus ilex L., Ph.D. thesis, Escuela Técnica Superior de Ingenieros de Montes, UPM, Madrid, 1998.

[57] Royo A., Fernández M., Gil L., Pardos J.A., Assessing hardiness of Aleppo pine, maritime pine and holm oak seedlings by electrolyte leakage and water potential methods, Tree Planters' Notes 50 (2003) 38-43.

[58] Simpson D.G., Frost hardiness, root growth capacity, and field performance relationships in interior spruce, lodgepole pine, Douglas-fir, and western hemlock seedlings, Can. J. For. Res. 20 (1990) 566-572.

[59] Sperry J.S., Donnelly J.R., Tyree M.T., A method for measuring hydraulic conductivity and embolism in xylem, Plant, Cell Environ. 11 (1988) 35-40.

[60] Spiro R.G., Analysis of sugars found in glycoproteins, in: Neufeld E.F., Ginsburg V. (Eds.), Methods in enzymology. Vol. VIII, Complex carbohydrates, Academic Press, New York, 1966, pp. 3-26.

[61] Tinus R.W., McDonald S.E., How to grow tree seedlings in containers in greenhouses, USDA Forest Service, Gen. Tech. Rep. RM-60, 1979.

[62] Van den Driessche R., Importance of current photosyntate to new root growth in planted conifer seedlings, Can. J. For. Res. 17 (1987) 776-782.

[63] Villar-Salvador P., Ocaña L., Peñuelas J., Carrasco I., Effects of water stress conditioning on the water relations, root growth capacity, and the nitrogen and non-structural carbohydrate concentration of Pinus halepensis Mill. (Aleppo pine) seedlings, Ann. For. Sci. 56 (1999) 459-465.

[64] Williams H.M., South D.B., Edwards M.B., Root growth potential and field survival of container loblolly pine seedlings fall fertilized with nitrogen, in: Proc. of the Eighth Biennial Southern Silvicultural Research Conference, Auburn, Alabama, Gen. Tech. Rep. Southern Research Station, USDA Forest Service, SRS-1, 1995, pp. 357-363.

[65] Youngberg C.T., Soil and tissue analysis: tools for maintaining soil fertility, in: Duryea M.L., Landis T.D. (Eds.), Forest nursery manual: production bareroot seedlings, Martinus Nijhoff/Dr. W. Junk Publishers, Boston, USA, 1984, pp. 75-80.

[66] Zaerr J.B., Cleary B.D., Scheduling irrigation to induce seedling dormancy, in: Proc. Intermountain Nurserymen's Association and Western Forest Nursery Association, USDA Forest Service, GTR, INT-109, 1981, pp. 74-79. 